JOURNAL OF SCIENTIFIC PERSPECTIVES

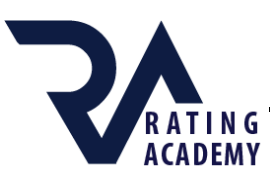

E-ISSN: 2587-3008

April 2018, Vol:2, Issue: 2

$J S P$

http://ratingacademy.com.tr/journals/index.php/jsp/

\title{
HISTOPATHOLOGICAL CHANGES IN THE STOMACH TISSUE OF RATS FED WITH MUSSELS (Mytilus galloprovincialis)
}

\author{
Assist. Prof. Dr. Mehmet Riza GEZEN*
}

Canakkale Onsekiz Mart University, Canakkale, Turkey, E-mail: mrgezen@comu.edu.tr

\section{ARTICLE INFO $\quad$ ABSTRACT}

Article History:

Received: 19 March 2018

Accepted: 26 April 2018

Keywords: Mussel,

Dardanelles, 8-hydroxy-2' -

deoxyguanosine,

Immunohistochemistry,

Stomach.

DOI: 10.26900/jsp.2018.14
Dardanelles is exposed to environmental pollution for many years. The strait is important in terms of fish migration and shellfish farming. Fish and shellfish obtained from the strait is frequently consumed by local people. Mussels serve as useful indicators of temporal trends in environmental quality because they accumulate some contaminants in their tissues at levels many time higher than in the surrrounding water and quickly to changes in contamination. Although there are few data about the toxicity of seafood that is exposed to environmental pollution, there are no animal studies about the gastric toxicity of mussels grown in the Dardanelles. Our previous studies demonstrated that the water and mollusc from certain regions of the Dardanelles contained heavy metal salts. The purpose of the study is to demonstrate the histopathologic changes in the gastric tissues of rats which are fed with mussels that are collected from the Çamburnu region of the Dardanelles. Four groups of rats are included in the study, group $1(n=6)$, control group fed with standard rat food, group $2(n=6), 75 \%$ mussels and $25 \%$ standard rat food daily, group $3(n=6), 75 \%$ mussels and $25 \%$ standard rat food every two days, group $4(n=6), 75 \%$ mussels and $25 \%$ standard rat food every three days. After the routine histopathologic processing all gastric tissue samples are evaluated in terms of 8-hydroxy-2' -deoxyguanosine (8-OHdG) immunoreactivity with light microscopy and image analysis software. No histopathologic differences found in standard hematoxylin-eosin (H.E.) stained gastric tissue samples of the control group. In the second and third groups, a small amount of mononuclear cell infiltration was detected. In the fourth group, no significant difference was observed in mononuclear cells. In immunohistochemical staining, 8-OHdG immunoreactivity in gastric epithelial cells. 8-OHdG immunoreactivity was negative in gastric tissues in all groups. There was no statistically significant difference between the groups that were fed every day, every other day and every three days with clam ( $p>0.05)$.

\section{INTRODUCTION}

All heavy metals are potentialy harmfull to most organisms at some level of exposure and absorption. Aquatic animals are also exposed to elevated levels of heavy metals. Some trace metals are essential in low concentrations fort he metabolism of animals, but in the excess all trace metala are toxic (Rainbow 1997). Trace metals such as $\mathrm{Cd}, \mathrm{Pb}, \mathrm{Hg}, \mathrm{Zn}$ accumulate mainly at the hepatopancreas, gonads and in the gills of molluscs and shellfishes. Therefore, mussels especially have been used as biological indicator organisms to monitor marine pollution by toxic heavy metals and potentially toxic chemicals due to their own properties of inhabitation (Pempkowiak et al., 1999; Hu, 2000). In recent years, heavy metal accumulation in fish and 
other aquatic organisms has been investigated along the coasta of Turkey. Sea of Marmara, Aegean Sea, Black Sea and Mediterranean Sea of have been exposed to more heavy metal pollution depending on industrial pollution from the different facilities, took place around it (Unsal and Besiktepe, 1994; Egemen et al., 2004; Goksu, 2005; Turkmen et al., 2005). The accumulation and effects of the organism depend on the characteristics of the composition of the arsenic and can cause chronic effects, DNA damage or cancers in the embryo (Dons and Beck 1993, Berg et al..1997). Guevara et al. (2004) found that some heavy metals (Ag, As, Cr, $\mathrm{Hg}$, Sb, Ba, Br, Ca, Co, Cs, Fe, Na, Sr, Zn), which are considered as potential contaminants, are in high amounts in the soft tissues of Diplodon chilensis (Gray 1828) type mussels. The level of heavy metal accumulation in water creatures depends on age, habitat and nutritional behavior. Heavy metal concentrations in coastal areas and closed seas are higher than open seas (Egemen 2000). Gezen (2011), Demir (2011) and Özkurnaz (2012) have detected heavy metals in sea water and many molluscan species that growing in the Dardanelles.

Heavy metals, such as mercury, cadmium, lead, copper, nickel, zinc, chromium and arsenic, have gained significance because they are toxic on certain concentrations and can increase their concentration during transition from one organism to another. Mussels are living organisms that are fed by filtering organic matter and phytoplankton in the water. The mussels can also filter toxic substances during water filtration. Pollution travels along food chains and can harm all living things, including humans (Julsham and Grahl-Nielsen 1996, Bat et.al. 1999).

Recent studies have suggested a close association between chronic inflammation and carcinogenesis in some organs. For example, patients with chronic viral hepatitis, inflammatory bowel disease, and Helicobacter pylori-associated gastritis are at higher risk for hepato-cellular carcinoma, colon cancer and gastric cancer, respectively. Although the precise mechanism sunderlying the development of malignant neoplasmsduring the course of chronic inflammation remain unclear, previous studies have suggested a possible involvement of oxidative DNA damage in this pro-cess (Seki et al.2002).

There is no research revealing histopathologic changes in the stomach tissues of living beings fed with mussels collected from the Çamburnu region in the Dardanelles (Çanakkale, Turkey).

The purpose of the study is to demonstrate DNA damage and the histopathologic changes in the gastric tissues of rats which are fed with mussels that are collected from the Çamburnu region in the Dardanelles (Çanakkale, Turkey).

\section{MATERIAL AND METHODS}

\subsection{Ethics Statement}

A total of 24 male Wistar albino rats, weighing 290-310 g, were used in the study. The study protocol was approved by the Çanakkale Onsekiz Mart University Ethics Committee for Animal Research (Protocol number: 2010/09-03).

\subsection{Animal Model}

The rats were kept for 30 days under appropriate conditions of temperature/humidity and a 12-h light cycle while being provided sufficient water and feed. The rats were randomly selected and divided into 4 groups. For the first study group (n: 6), was the control group; standard rat diet was given every days. For the second study group (n: 6), $75 \%$ mussels $+25 \%$ standard rat diet standard rat feeds were given daily. For the third study group (n: 6), 75\% mussels $+25 \%$ standard rat diet was given every two days. Standard rat diet was given the other 
day. For the fourth group (n: 6), $75 \%$ mussels $+25 \%$ standard rat diet was given every three days. Standard rat diet was given the other two day.

Rats were fed twice daily for 30 days at $15 \%$ of their weight every morning and evening at the same time. The mussels given as food to the rats were removed from the Dardanelles Çamburnu region (Figure 1). Average $70 \pm 10 \mathrm{~g}$ weight were selected. After the beaks were overcooked, the meat broke off and the meat at 100 degrees was dried.

It was weighed into each rat's weight and $10 \mathrm{mg} / \mathrm{kg}$ intraperitoenal ketamine hydrochloride (Ketalar, Eczacibasi, Istanbul, Turkey), and $20 \mathrm{mg} / \mathrm{kg}$ of xylazine $2 \%$ (Rompun, Bayer Turkey Pharmaceutical Ltd., Istanbul, Turkey) were anesthetized. The rats were anesthetized and then sacrificed. After the rats have received the stomachs other organs were also taken for further research.

\subsection{Histological evaluation}

The stomach tissues were maintained in immunofix (Leica) for 24 hours for histopathological examination. The paraffin embedded stomach tissues were stained with hematoxylin and eosin $(\mathrm{H} \& \mathrm{E})$ at a thickness of 5 microns. Immunohistochemical staining method was applied by cutting the paraffin embedded stomach tissues 3 microns in thickness.

For 8-hydroxydeoxyguanosine (8-OHdG) staining, tissue samples were incubated at 37 ${ }^{\circ} \mathrm{C}$ in Proteinase K (dilution 1: 30, Millipore Corporation) for $40 \mathrm{~min}$. and then waited in the laboratory until the room was warmed up. Subsequently, tissue samples were resuspended in 0.2\% Triton X 100 (Santa Cruz Biotechnology) solution prepared with Phosphate Buffer Saline (PBS, Invitrogen) for $5 \mathrm{~min}$. were kept. This allowed better passage of solutions from the pores in the cell and nucleus membranes. The tissue samples confined to the Pap pen were washed three times with PBS for 3 min. Peroxidase block solution (Diagnostic BioSystems) was placed on each tissue sample to block the peroxidase enzyme in the cell and incubated for $30 \mathrm{~min}$. waiting for a while. Subsequently, this solution was dissected and each tissue sample was washed three times with PBS for 3 min. (LAB-SA Detection System, Histostain-Plus Bulk Kit, Invitrogen) was placed on each sample and the remaining PBS solution was rinsed with the drying paper and incubated for $30 \mathrm{~min}$. waiting for a while. Subsequently, each tissue sample was purged with drying paper by pouring serum blocking solution. Tissue specimens we separated as negative controls were loaded with serum blocking solution and polyclonal goat anti-8-Hydroxydeoxyguanosine (8-OHDG, dilution 1: 200, Millipore Corporation) primer antibodies on other tissue samples. Subsequently, each tissue sample was washed three times with PBS for $3 \mathrm{~min}$. The PBS solution remaining around each sample was purged with the drying paper and a solution of 3,3'-Diaminobenzidene tetrahydrochloride (DAB, Invitrogen Corporation) was added as a chromogen. kept in dark place for a while. At the end of this period, DAB solution was poured over the tissue specimens and water was dewatered. Tissue samples were taken 2 times and 2 min. for 5 minutes in Mayer's Hematoxylin for counter-staining. and kept in the tap water for 10 minutes. Washed. Subsequently, xylene and graded alcohols were passed through and entrapped (Bio Mount, Bio-Optica).

Dye samples were evaluated on the Zeiss AXIO Scope 1 brand research microscope. Analysis of iNOS immunoreactive cells in the stomach tissue was performed using the Leica LAS V3.8 image analysis system. Five of the sections from the blocks containing the stomach tissues of all the rats in all groups were stained. From the stained sections, 1000 cells were counted and immunoreactive cells were identified among these cells. Tosun et al. (2006), Bakir et al. (1996), and Avunduk et al. (2000) for this purpose;

Immune-positive cells 
Total cell count (1000)

SPSS 15 version was applied for the statistical evaluation of the results obtained with the applied formula. Kruskal-Wallis Test was used for nonparametric tests to determine the differences between iNOS immunoreactivity groups. The difference between the groups was considered significant in the results of $\mathrm{p}<0.05$.

\section{RESULT}

There was no significant change in the staining of the stomach of the rats in the first group with Hematoxylin Eosin (Figure 2). In the second group, a small amount of mononuclear cell infiltration was detected (Figure 3). In the third a small amount of mononuclear cell infiltration was detected (Figure 4) In the fourth group (Figure 5), no significant difference was observed in mononuclear cells. 8-OHdG immunoreactivity was negative in stomach tissues in all groups. No significant differences were detected between groups in immunohistochemical staining with 8-OHdG (Figure 6).

\section{CONCLUSION}

In this study, we found mononuclear inflammatory cell in gastric mucosa of rats fed with mussels containing heavy metal salts.

Gezen et al. (2011) has investigated the accumulation of heavy metals in the carpet shell clam, clam, sea snails and oysters from the Dardanelles Umurbey region. In this research, $\mathrm{Zn}$ in carpet shell clams, $\mathrm{Zn}$ and $\mathrm{Mn}$ in clams, $\mathrm{Zn}$ in oysters, $\mathrm{Al}, \mathrm{Zn}, \mathrm{Fe}, \mathrm{Cu}$ and $\mathrm{Mn}$ in sea snails found the metals as high. If the same zone is in seawater, the $\mathrm{Zn}$ level is high. In sea chestnuts growing in Dardanells, the values of $\mathrm{Al}, \mathrm{Zn}$, and Fe in samples taken from Gelibolu Hamzakoy station are high. $\mathrm{Al}$ and $\mathrm{Fe}$ values were higher in samples taken from Çardak region. $\mathrm{Al}, \mathrm{Fe}$ and $\mathrm{Zn}$ values were higher in samples taken from Umurbey region. Al, Fe and $\mathrm{Zn}$ values were higher in samples taken from Çamburnu region (Gezen et al. 2011). Demir et al. (2011) has investigated the accumulation of heavy metals in the carpet shell clam, clam, sea snails and oysters from the Dardanelles Karacaören region. In this research, Al, $\mathrm{Zn}$ and Fe in carpet shell clams, $\mathrm{Zn}$ and $\mathrm{Mn}$ in clams, $\mathrm{Zn}$ in oysters, $\mathrm{Al}, \mathrm{Zn}, \mathrm{Fe}, \mathrm{Cu}$ and $\mathrm{Mn}$ in sea snails found the metals as high.

IARC (1987) has explained that heavy metals may affect and cause chronic degenerative changes and, in some cases, teratogenic and carcinogenic effects, especially by affecting the nervous system, liver and kidneys. In addition to the findings of other researchers, we have also found that heavy metal salts cause histopathological changes in the stomach.

Gezen (2017) stated that immunohistochemical staining methods are used to detect damage to cells and tissues. The positive cells $(8-\mathrm{OHdG})$ were predominantly observed in the areas of active inflammation with prominent cell infiltration (Seki et al. 2002). In this study, we investigated whether or not to produce DNA damage by feeding the mussels containing heavy metal salts to rats. However, 8-OHDG was found to be negative in the gastric mucosa of all groups in our study. It is thought that heavy metals in low levels (NOEL) in the grains do not cause DNA damage.

It is a very consumed food material, especially if the people of the region are in need of mussel filling in many settlements which are coastal. Considering that mussel stuffs are consumed in large quantities at once, it is thought that serious digestive system diseases can occur when mussels are exposed to environmental factors such as heavy metals, peptides and waste water. 
GEZEN / Histopathological Changes in The Stomach Tissue of Rats Fed with Mussels (Mytilus galloprovincialis) 


\section{REFERENCES}

AVUNDUK, M.C., TAVLI, Ș., YOL, S., TAVLI, L., YAVUZ, A., GÜNGÖR, S., YILMAZ, O., 2000. Mide karsinomlarında hücre proliferasyon belirleyicisi olarak PCNA, Ki 67 ve agNOR kullanımı. Ankara Üniversitesi Tıp Fakültesi Mecmuası, 53(1): 11-15.

BAKIR, K., KAPUCUOĞLU, N., BÜLBÜL, H.D., 1996. PCNA (Proliferating Cell Nuclerar Antigene) immunohistokimyasal boyanması ve agNORs'un meme karsinomunda prognozu belirlemedeki rolü. Türk Patholoji Dergisi, 12(1): 35-38.

BAT, L, GÜNDOĞDU, A., ÖZTÜRK, M., ÖZTÜRK, M., 1999. Copper, zinc, lead and cadmium concentrations in the Mediterranean mussel Mytilus galloprovincialis ( $\mathrm{L}$. 1718) from the Sinop coast of the Black Sea. Turk J Zool. 23; 321-326.

BERG, V., ERIKSON, G.S., IVERSON, P.E., 1997. Strategies for monitoring of contamiants in marine organisms in Norwegian harbours and fjords. Norwegian State Food Control Reports. 94: 300-321.

DEMIR, N., GEZEN, M.R., BALLI, M., 2011. Çanakkale Boğazı'nın Karacaören Kıyısındaki Deniz Suyu ve Bazı Yumuşakçalarda (Bivalvia ve Gastropoda) Ağır Metal Düzeylerinin Araştırılması. Ekoloji Sempozyumu, P1: 39, Düzce.

DONS C. and BECK P.A., 1993. Priority hazardous substances in Norway. Norwegian State Pollution Control Reports 93: 22-115.

EGEMEN Ö. Çevre ve Su Kirliliği. Ege Üniversitesi Su Ürünleri Fakültesi Yayınları, No: 42, Bornova-İzmir, 2000.

EGEMEN, Ö., ALPARSLAN, M., SUNLU, U.,2004. Çanakkale'de toplanan midyelerde (Mytilus galloprovincialis) bazı ağır metal düzeylerinin araştırılması. E.Ü. Su Ürünleri Dergisi, 14: 189-196.

GEZEN, M.R., DEMIR, N., ÇETIN, M., 2011. Çanakkale Boğazı'nın Umurbey Kıyısındaki Deniz suyu ve Bazı Yumuşakçalarda (Bivalvia ve Gastropoda) Ağır Metal Düzeylerinin Araştırılması. Ekoloji Sempozyumu, P2: 11, Düzce.

GEZEN, M.R., DEMIR, N., ÇETIN, M., BALLI, M., 2011.Çanakkale Boğazı'ndaki Deniz Kestanesi (Paracentrotus lividus)' nin Ağır Metal Düzeyleri Üzerinde Bir Araştırma. Ekoloji Sempozyumu, P2: 10, Düzce.

GEZEN, M.R., 2017. Histopathological Research and Diagnosis of Important Paiting Methods, Journal of Scientific Perspectives, 1(1): 23-27.

GUEVARA, S.R., BUBACH, D., VIGLIANO, P., LIPPOLT, G., ARRIBERE, M., 2004. Heavy metal and other traceelements in native mussel Diplodon chilensis from Northern Patagonia Lakes, Argentina. Biol Trace Elem Res 102(1-3): 245-263.

GÖKSU, M.Z.L., AKAR, M., ÇEVİK, F., FINDIK, Ö., 2005. Bioaccumulation of some heavy metals (Cd, Fe, Zn, Cu) in two bivalvia species. Turk. J. Vet. Anim. Sci., 29: 89-93.

HU, H., 2000. Exposure to metals. Prim Care, 27; 983-996.

JULSHAMN, K., GRAHL-NIELSEN, O., 1996. Distribution of trace elemets from industrials discharges in the Hardangerfjord, Norway. A multivariate data-analysis of saithe, flounder, and blue mussel as sentinel organisms. Marine Pollution Bulletin 32: 564571.

PEMPKOWIAK, J., SIKORA, A., BIERNACKA, E., 1999. Specification of heavy metals in marine sediments, their bioaccumulation by mussels. Chemosphere, 39: 313-321. 
RAINBOW, P.S., 1997. Ecophysiology of trace metal uptake in crustaceans. Estuarine, Coastal and Shelf Science 44:169-75.

ÜNSAL, M., BEŞİKTEPE, S.A., 1994. A preliminary study on the metal content of mussels, Mytilus galloprovincialis in the Eastern Black Sea. Tr. J. Zoology, 18; 265-271.

SEKI, S., KITADA, T., YAMADA, T., SAKAGUCHI, H., NAKATANI, K., ONODA, N., SATAKE, K., 2002. Immunohistochemical detection of 8-hydroxydeoxyguanosine, a marker of oxidative DNA damage, in human chronic cholecystitis. Histopathology, 40: 531-535.

TOSUN, E., TOSUN, M., AVUNDUK, M.C., 2006. Hücre çoğalma belirleyicilerinin meme infiltratif duktal karsinomlarında progrostik amaçlı kullanımı. Optimal Tıp Dergisi, 19(2): 27-40.

TÜRKMEN, A., TÜRKMEN, M., TEPE, Y., 2005. Biomonitoring of heavy metals from Iskenderun Bay using two bivalve species Chama pacifica Broderip,1834 and Ostrea stentina Payraudeau, 1826. Turkish J. Fish. Awuatic Sci., 5: 107-111. 


\section{FIGURES}

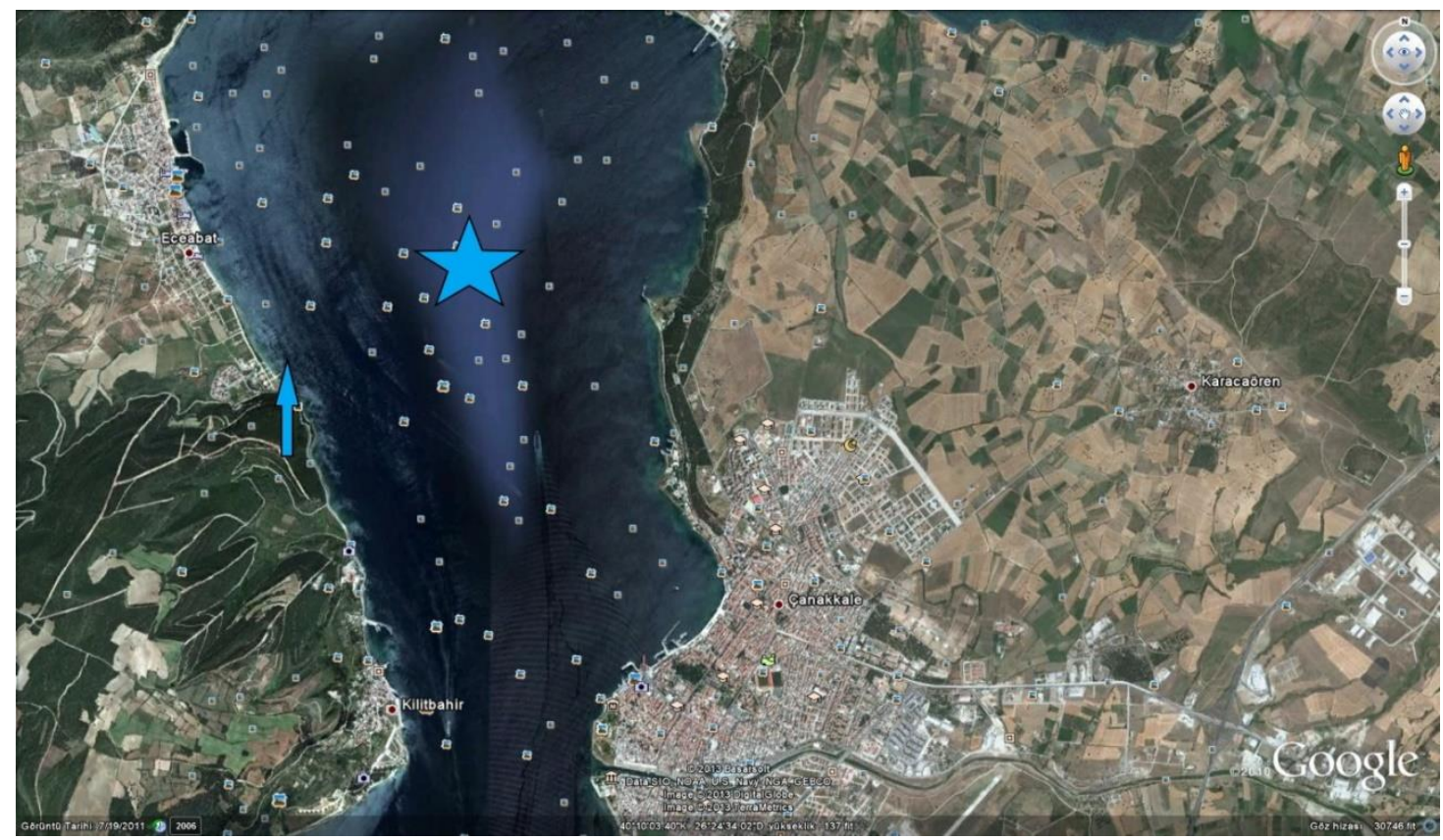

Figure 1: The area where the mussels are collected

Arrow: Çamburnu region (Çanakkale, Turkey)

Star: Dardanelles

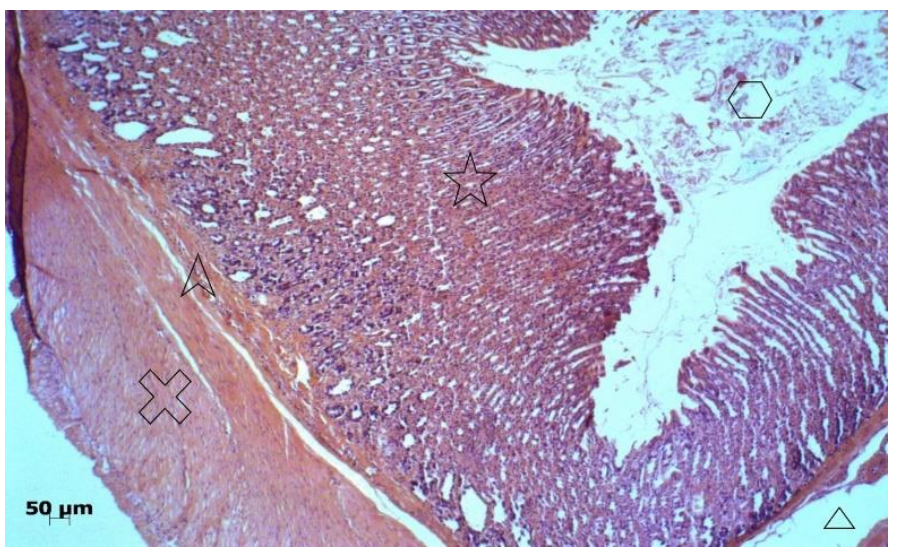

Figure 2. For the first study group was the control group; standard rat diet was given every days. Rat stomach, (H.E. x 5).

Star: Lamina propria mucosa

Pointed arrow: Lamina muscularis mucosa

Arrow head: Lamina submucosa

Crossed: Tunica muscularis

Hexagon: Gastric lumen 


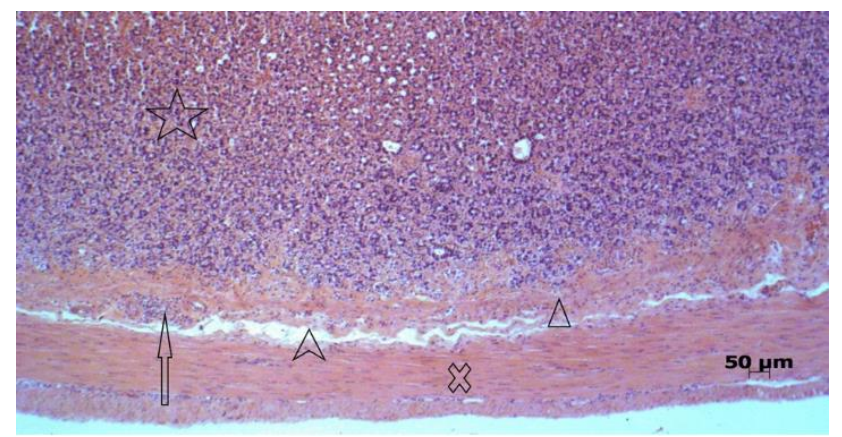

Figure 3. For the second study group; $75 \%$ mussel $+25 \%$ standard rat diet standard rat feeds were given daily. Rat stomach, (H.E. x10).

Star: Lamina propria mucosa

Arrow head: Lamina muscularis mucosa

Pointed arrow: Lamina submucosa

Crossed: Tunica muscularis

Arrow: Mononuclear inflammatory cells

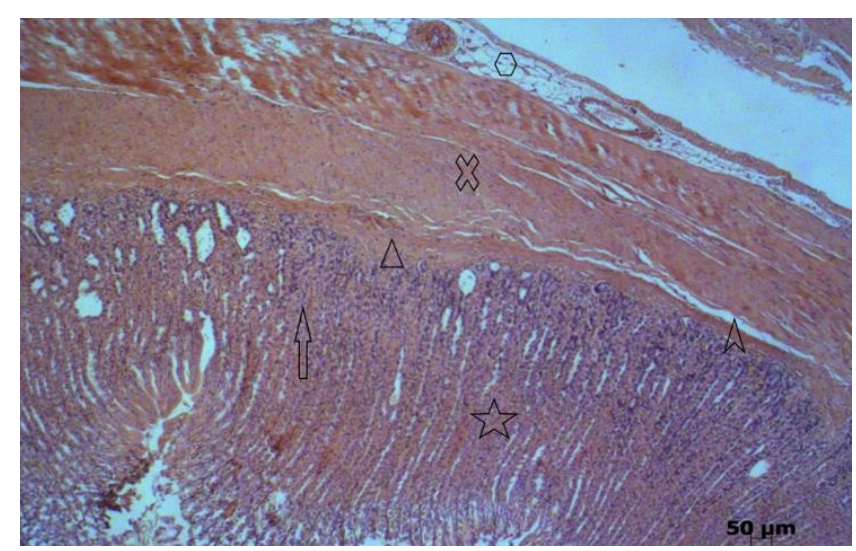

Figure 4. For the third study group; $75 \%$ mussel $+25 \%$ standard rat diet was given every two days. Standard rat diet was given the other day. Rat stomach, (H.E. x 5).

Star: Lamina propria mucosa

Arrow head: Lamina muscularis mucosa

Pointed arrow: Lamina submucosa

Crossed: Tunica muscularis

Hexagon: Tunica adventitia

Arrow: Mononuclear inflammatory cells 


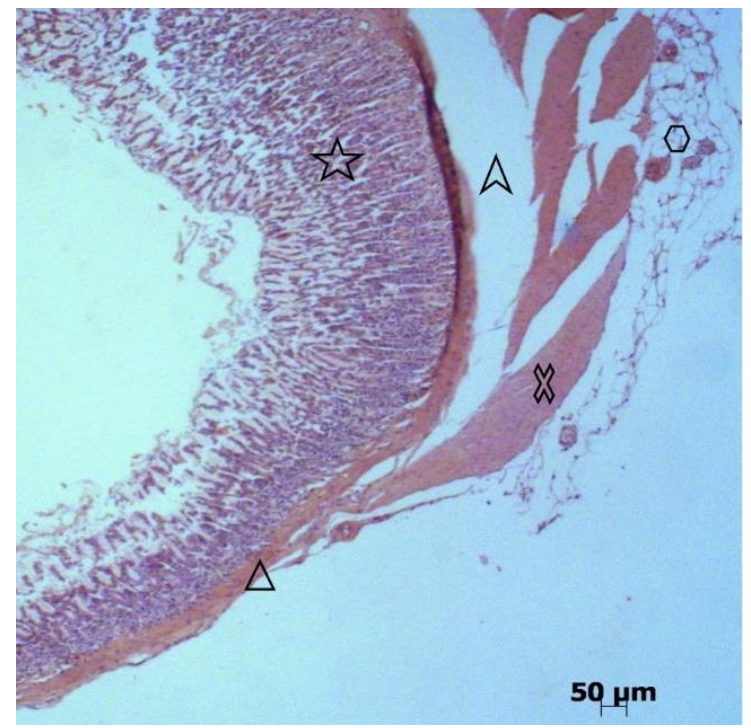

Figure 5. For the fourth group; $75 \%$ mussel $+25 \%$ standard rat diet was given every three days. Standard rat diet was given the other two day. Rat stomach, (H.E. x10).

Star: Lamina propria mucosa

Arrow head: Lamina muscularis mucosa

Pointed arrow: Lamina submucosa

Crossed: Tunica muscularis

Hexagon: Tunica adventitia

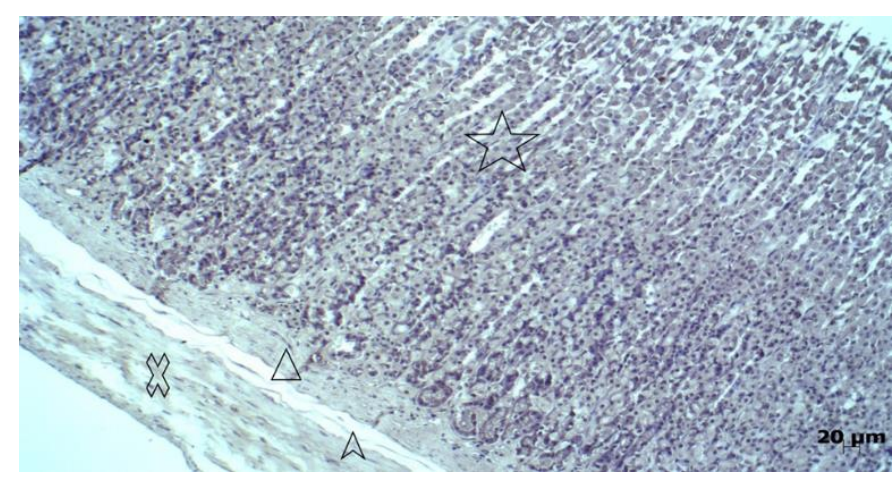

Figure 6. For the second study group; $75 \%$ mussel $+25 \%$ standard rat diet standard rat feeds were given daily. Rat stomach. (8-OHdG x 10)

Star: Lamina propria mucosa

Arrow head: Lamina muscularis mucosa

Pointed arrow: Lamina submucosa

Crossed: Tunica muscularis 
GEZEN / Histopathological Changes in The Stomach Tissue of Rats Fed with Mussels (Mytilus galloprovincialis)

\section{Abbreviation:}

$\mathrm{H} \& \mathrm{E}$ : hematoxylin and eosin,

8-OHdG: 8-hydroxy-2' -deoxyguanosine,

NOEL: no-observed-adverse-effect level,

IARC: International Agency for Research on Cancer 
GEZEN / Histopathological Changes in The Stomach Tissue of Rats Fed with Mussels (Mytilus galloprovincialis) 